\title{
ВПЛИВ L-АРГІНІНУ ТА АМІНОГУАНІДИНУ НА РІВЕНЬ СИНТЕЗУ ОКСИДУ АЗОТУ В МОЗОЧКУ І ВЕЛИКИХ ПІВКУЛЯХ ГОЛОВНОГО МОЗКУ ЗА УМОВ ЕКСПЕРИМЕНТАЛЬНОГО АНТИФОСФОЛІПІДНОГО СИНДРОМУ
}

Вступ. Антифросфроліпідний синдром (АФС) - це аутоімунне захворювання, яке характеризується наявністю антифросфроліпідних антитіл, артеріальними та венозними тромбозами, тромбоцитопенією, невиношуванням вагітності.

Мета дослідження - вивчити вплив комбінованої дії L-аргініну й аміногуанідину на вміст нітрит- $i$ нітрат-аніонів у мозочку та великих півкулях головного мозку мишей лінії BALB/c з антифоссроліпідним синдромом до і на 18-й день вагітності.

Meтоди дослідження. Дослідження виконували на мишах-самках лінії BALB/c із змодельованим AФC. Для корекції використовували L-аргінін (25 мг/кг) у комбінації з аміногуанідином (10 мг/кг). Про вміст оксиду азоту в гомогенатах мозочка та великих півкулях головного мозку тварин з АФС до і на 18-й день вагітності робили висновок за кількістю його стабільних метаболітів - нітрит-аніонів ( $\left.\mathrm{NO}_{2}^{-}\right)$і нітрат-аніонів $\left(\mathrm{NO}_{3}^{-}\right)$.

Результати й обговорення. У мишей лінії $B A L B / C$ з АФС у мозочку та великих півкулях головного мозку зростав вміст стабільних метаболітів оксиду азоту - $\mathrm{NO}_{2}^{-}$i $\mathrm{NO}_{3}^{-}$порівняно з показниками інтактних тварин. При експериментальному АФС на 18-й день вагітності вміст $\mathrm{NO}_{2}^{-}$i $\mathrm{NO}_{3}^{-}$у мозочку збільшувався, а у великих півкулях головного мозку тварин з АФС - зменшувався відносно контролю. На тлі комбінованого введення мишам з АФС попередника синтезу оксиду азоту L-аргініну та селективного інгібітора індуцибельної NO-синтази аміногуанідину відзначали зниження вмісту NO${ }_{2}^{-}$i NO${ }_{3}^{-}$у мозочку (на 28 ma 17 \%) і великих півкулях головного мозку (на 16 та 10 \%) порівняно з показниками тварин з АФС. У вагітних мишей лінії BALB/c з АФС, яким вводили L-аргінін у комбінації з аміногуанідином, спостерігали зменшення вмісту $\mathrm{NO}_{2}^{-}$на $29 \%$ та NO$_{3}^{-}$на $25 \%$ у мозочку, збільшення рівня $\mathrm{NO}_{2}^{-}$на $21 \%$ і $\mathrm{NO}_{3}^{-}$на $22 \%$ у великих півкулях головного мозку відносно вагітних самок з АФС.

Висновок. Комбіноване застосування L-аргініну й аміногуанідину призводить до нормалізації рівня стабільних метаболітів синтезу оксиду азоту - $\mathrm{NO}_{2}^{-}$i $\mathrm{NO}_{3}^{-}$у мозочку та великих півкулях головного мозку мишей лінії BALB/с за умов АФС до і на 18-й день вагітності.

КЛЮЧОВІ СЛОВА: антифоссооліпідний синдром; вагітність; оксид азоту; мозочок; великі півкулі головного мозку.

ВСТУП. Антисроссроліпідний синдром (АФС) це аутоімунне захворювання, яке характеризується порушенням фрункцій серцево-судинної і центральної нервової систем, печінки, нирок, шлунково-кишкового тракту, ендокринних залоз, тромбоцитопенією [1-4]. До критеріїв діагностики АФС належать наявність антифоссроліпідних антитіл (аФЛ), артеріальні та венозні тромбози різної локалізації, невиношування вагітності $[5,6]$.

Основним неврологічним проявом АФС $€$ ішемічні порушення мозкового кровообігу, зумовлені тромбозами артерій мозку, розвиток яких патогенетично пов'язаний із синтезом аФЛ. У хворих з аФЛ, крім порушень мозкового крово(с) О. 3. Яремчук, К. А. Посохова, І. П. Кузьмак, 2019. обігу, спостерігають інші неврологічні прояви, які не пов'язані з тромбозами (невропатія, головний біль, епілепсія, хорея) [5].

У механізмах розвитку АФС важливу роль відіграють антитіла до $\beta$-2-глікопротеїну-І (ß2GPI). Зв'язування цих антитіл аФЛ з антигенами на клітинній поверхні ендотеліальних клітин, моноцитів, трофообластів і тромбоцитів запускає внутрішньоклітинну активацію. Активація тромбоцитів та вивільнення тромбоксану сприяють їх агрегації. Активація ендотеліальних клітин та моноцитів впливає на регуляцію експресії молекул адгезії, таких, як Е-селектин, вивільнення тканинного фрактора (TF) і прозапальних цитокінів [1, 7-9]. 
При гестаційному АФС спостерігають гіперкоагуляцію, яка виникає під впливом аФЛ, розвиток тромбозів у мікроциркуляторному руслі, плацентарної недостатності, хронічної гіпоксії, нерідко - загибель плода внаслідок гострого порушення кровообігу в судинах плаценти [10].

Система оксиду азоту (NO) відіграє важливу роль у механізмах розвитку АФС $[11,12]$. Доведено, що при цьому синдромі порушуються синтез і біодоступність NO $[13,14]$. За даними інших дослідників [15], збільшення концентрації нітратів у пацієнтів з АФС свідчить про порушення фрункції ендотелію. Значне зниження рівня NO призводить до абортів та передчасних пологів. 3 іншого боку, гіперпродукування NO опосередковане індуцибельною ізофрормою NO-синтази (iNOS, 1.14.13.39), збільшує маткові скорочення і ризик невиношування вагітності [10].

За даними В. П. Реутова та співавт., NO відіграє роль інтегруючого елемента у функціонуванні нервової системи, що становить єдність нервової, гуморальної, міжклітинної і внутрішньоклітинної регуляції мозку із системою кровообігу [16]. В центральній нервовій системі NO синтезується в нейронах, клітинах мікроглії та ендотелії кровоносних судин, нейрогліальних клітинах. Оксид азоту контролює осциляторну активність нейронів і модулює синаптичну пластичність, міжнейрональні комунікації, внутрішньоклітинну передачу сигналу, стан рецепторів, вивільнення нейротрансмітерів [17].

Патобіохімічні механізми АФС висвітлено достатньо [1, 5, 7-9, 14], проте є лише поодинокі дослідження про участь NO в розвитку ураження головного мозку за умов АФС. Відсутність єдиної точки зору щодо ролі NO в патогенезі АФС $€$ підґрунтям для проведення досліджень у цьому напрямку.

Мета дослідження - вивчити вплив комбінованої дії L-аргініну й аміногуанідину на вміст нітрит- і нітрат-аніонів у мозочку та великих півкулях головного мозку мишей лінії BALB/c 3 антисоосфоліпідним синдромом до і на 18-й день вагітності.

МЕТОДИ ДОСЛІДЖЕННЯ. Дослідження виконували на мишах-самках лінії BALB/c, яких утримували на стандартному раціоні віварію. Експерименти проводили 3 дотриманням принципів біоетики відповідно до Загальних етичних принципів експериментів на тваринах (Київ, 2001) та Директиви Європейського Союзу 2010/10/63 EU щодо експериментів на тваринах.

Антифоссроліпідний синдром моделювали за допомогою кардіоліпіну ("Sigma", США), який вводили внутрішньом'язово 4 рази (30 мкг на одну ін'єкцію, проміжки між ін'єкціями становили
14 діб) [18]. Для підвищення ефективності імунної відповіді кардіоліпін емульгували в 75 мкл повного ад'юванту Фрейнда (перша ін'єкція), наступні ін'єкції проводили з неповним ад'ювантом Фрейнда. Антифоосфоліпідний синдром формувався через 2 тижні після останньої ін'єкції кардіоліпіну. Для підтвердження розвитку АФС проводили реакцію мікропреципітації з кардіоліпіновим антигеном, з використанням тест-системи "Антиген кардіоліпіновий, для реакції мікропреципітації” (“Біолік”, Україна) [18].

Піддослідних тварин поділили на 6 груп: 1-ша і 4-та (контроль) - інтактні; 2-га та 5-та - миші 3 АФС; 3-тя і 6-та - тварини з АФС, яким вводили внутрішньочеревно L-аргінін ("Sigma”, США, 25 мг/кг) та аміногуанідин ("Химлабораторреактив", Україна, 10 мг/кг). Через 10 діб з моменту підтвердження АФС мишей 1-3 груп виводили 3 експерименту за умов тіопентал-натрієвого наркозу (внутрішньочеревне введення $1 \%$ розчину з розрахунку 50 мг/кг маси тіла тварини). Самок 4-6 груп спарювали із самцями у співвідношенні 1 самець на 3 самки. Для підтвердження вагітності вивчали вагінальні мазки [18]. Виводили тварин з експерименту на 18-й день вагітності.

Тканину мозочка та великих півкуль головного мозку охолоджували в середовищі виділення, яке містило 0,25 М сахарози, 1 мМ ЕДТА та 10 мМ трис-HCl-бусрера (pH 7,4) [19]. Про вміст NO в мозочку і великих півкулях головного мозку робили висновок за кількістю його стабільних метаболітів - нітрит-аніонів $\left(\mathrm{NO}_{2}^{-}\right)$та нітрат-аніонів $\left(\mathrm{NO}_{3}^{-}\right)$. Вміст $\mathrm{NO}_{2}^{-}$визначали високоспецифрічним спектрофотометричним методом Гріна за даними кольорової реакції з реактивом Гріса [20]. Відновлення нітратів до нітритів здійснювали металічним цинком в оцтовокислому розчині. Іони $\mathrm{NO}_{2}^{-}$виявляли діазореакцією з реактивом Гріса 3 наступним колориметричним визначенням [21].

Статистичну обробку даних проводили за допомогою програми STATISTICA 10. Порівнювали отримані величини з використанням U-критерію Манна - Уїтні. Зміни вважали достовірними при $\mathrm{p} \leq 0,05$.

РЕЗУЛЬТАТИЙ ОБГОВОРЕННЯ. ЯК ПОКаЗали результати наших досліджень, у групах тварин, яким моделювали АФС (2-3 та 5-6 групах), реакція мікропреципітації з кардіоліпіновим антигеном була позитивною, що підтверджувало розвиток АФС [18].

Однією з ланок, що беруть участь у патобіохімічних механізмах розвитку АФС, є система NO $[11,14,22]$. Оксид азоту синтезується 3 амінокислоти L-аргініну з участю 3-х ізоформ NO-синтази (1.14.13.39): нейрональної (nNOS), 
ендотеліальної (eNOS) та індуцибельної (iNOS) $[16,23]$. Функції NO як вторинного месенджера пов'язані із взаємодією з гемовмісними протеїнами, насамперед із розчинною гуанілатциклазою, що каталізує синтез циклічного гуанозинмоносроссрату. Оксид азоту може впливати на клітинні фрункції шляхом прямої (нітрозилювання) або непрямої (метилювання і рибозилювання) посттрансляційної модифрікації протеїнів. Крім регуляторних фрункцій, він проявляє цитотоксичну активність, утворюючи в реакції із супероксидним радикалом пероксинітрит (ONOO') [16, 17, 24]. Нейрони, які синтезують NO, становлять близько 1-2 \% від загальної кількості нервових клітин центральної нервової системи. В основному він синтезується в мозочку і середньому мозку [17, 23].

Встановлено, що у групі мишей з АФС вміст у мозочку стабільних метаболітів оксиду азоту зростав порівняно з показниками інтактних тварин: $\mathrm{NO}_{2}^{-}-$на $46 \%, \mathrm{NO}_{3}^{-}$- на $41 \%$ (табл. 1). У великих півкулях головного мозку мишей лінії BALB/c з AФC він також підвищувався відносно контролю: $\mathrm{NO}_{2}^{-}$- на $28 \%, \mathrm{NO}_{3}^{-}-$на $20 \%$ (див. табл. 1).

Збільшення eNOS-залежного синтезу NO захищає організм від вільнорадикального ушкодження, тромбозів, гіпертензії, спазмів судин. Гіперпродукування iNOS-залежного NO пригні- чує синтез ДНК, ензими циклу Кребса та тканинного дихання [17, 23]. За даними літератури, підвищений синтез NO в головному мозку супроводжується зростанням рівня $\mathrm{NO}_{2}^{-}$i $\mathrm{NO}_{3}^{-}$у крові та лікворі пацієнтів [24]. За даними P. R. Ames та співавт. [11], у людей з АФС рівень плазмових аФЛ перебуває у зворотному зв'язку з кількістю метаболітів NO, які виділяються із сечею. Експериментальні та клінічні дослідження підтверджують зв'язок між АФС та порушенням біодоступності NO [13, 25].

У результаті проведених досліджень встановлено, що в мишей лінії BALB/с з АФС на 18-й день вагітності вміст у мозочку стабільних метаболітів оксиду азоту зростав порівняно з показниками вагітних тварин контрольної 4-ї групи: $\mathrm{NO}_{2}^{-}$- на $54 \%, \mathrm{NO}_{3}^{-}$- та $65 \%$ (табл. 2). У досліджуваних зразках великих півкуль головного мозку вагітних мишей лінії BALB/c за умов АФС відзначали зниження вмісту $\mathrm{NO}_{2}^{-}$на $15 \%$ та $\mathrm{NO}_{3}{ }^{-}$на 19 \% відносно контролю (див. табл. 2). Отримані результати досліджень узгоджуються з даними літератури про те, що синтез і біодоступність NO порушуються при акушерському АФС [10]. Це може бути пов'язано як із недостатністю субстрату для синтезу NO L-аргініну, так і з утворенням підвищеного рівня супероксиданіона, який швидко зв'язує та інактивує NO $[12,15]$.

Таблиця 1 - Вміст нітрит- і нітрат-аніонів у мозочку та великих півкулях головного мозку мишей лінії BALB/c при антифоссфоліпідному синдромі й комбінованому застосуванні L-аргініну та аміногуанідину (M $\pm m, n=10)$

\begin{tabular}{||l|c|c|c|c|}
\hline \multirow{2}{*}{\multicolumn{1}{|c|}{ Група тварин }} & \multicolumn{4}{|c|}{ Показник } \\
\cline { 2 - 5 } & \multicolumn{3}{|c|}{ мозочок } & \multicolumn{2}{c|}{ великі півкулі головного мозку } \\
\cline { 2 - 5 } & $\begin{array}{c}\mathrm{NO}_{2}^{-}, \\
\text {мкмоль/кг }\end{array}$ & $\begin{array}{c}\mathrm{NO}_{3}^{-}, \\
\text {мкмоль/кг }\end{array}$ & $\begin{array}{c}\mathrm{NO}_{2}^{-}, \\
\text {мкмоль } / \text { кг }\end{array}$ & $\begin{array}{c}\mathrm{NO}_{3}^{-}, \\
\text {мкмоль/кг }\end{array}$ \\
\hline Контроль & $3,37 \pm 0,08$ & $16,76 \pm 0,45$ & $2,79 \pm 0,08$ & $14,78 \pm 0,34$ \\
\hline АФС & $4,90 \pm 0,14$ & $23,71 \pm 0,83$ & $3,57 \pm 0,15$ & $17,69 \pm 0,52$ \\
& $\mathrm{p}<0,001$ & $\mathrm{p}<0,001$ & $\mathrm{p}<0,005$ & $\mathrm{p}<0,005$ \\
\hline АФС+L-аргінін+аміногуанідин & $3,55 \pm 0,08$ & $19,73 \pm 0,91$ & $3,02 \pm 0,14$ & $15,93 \pm 0,33$ \\
& $\mathrm{p}_{1}<0,001$ & $\mathrm{p}_{1}<0,05$ & $\mathrm{p}_{1}<0,05$ & $\mathrm{p}_{1}<0,05$ \\
\hline
\end{tabular}

Примітка. Тут і в таблиці 2: p - достовірна відмінність від відповідних значень в інтактних тварин; $p_{1}-$ достовірна відмінність від відповідних значень у групі тварин з АФС.

Таблиця 2 - Вміст нітрит- і нітрат-аніонів у мозочку та великих півкулях головного мозку вагітних мишей лінії BALB/c при антифоссроліпідному синдромі й комбінованому застосуванні L-аргініну та аміногуанідину (M $\pm m, n=10)$

\begin{tabular}{|c|c|c|c|c|}
\hline \multirow{3}{*}{ Група тварин } & \multicolumn{4}{|c|}{ Показник } \\
\hline & \multicolumn{2}{|c|}{ МОзочОК } & \multicolumn{2}{|c|}{ великі півкулі головного мозку } \\
\hline & $\begin{array}{c}\mathrm{NO}_{2}^{-}, \\
\text {МКМОЛЬ/Кг }\end{array}$ & $\begin{array}{c}\mathrm{NO}_{3}^{-}, \\
\text {мкмоль/кг }\end{array}$ & $\begin{array}{c}\mathrm{NO}_{2}^{-}, \\
\text {МКМОЛЬ/Кг }\end{array}$ & $\begin{array}{c}\mathrm{NO}_{3}^{-}, \\
\text {мКмоль/кг }\end{array}$ \\
\hline Контроль & $3,45 \pm 0,07$ & $17,73 \pm 0,77$ & $2,86 \pm 0,09$ & $15,48 \pm 0,81$ \\
\hline $\mathrm{A} \Phi \mathrm{C}$ & $\begin{array}{c}5,31 \pm 0,14 \\
p<0,001\end{array}$ & $\begin{array}{c}29,29 \pm 1,28 \\
p<0,001\end{array}$ & $\begin{array}{c}2,43 \pm 0,10 \\
p<0,05\end{array}$ & $\begin{array}{c}12,56 \pm 0,33 \\
p<0,05\end{array}$ \\
\hline AФC+L-аргінін+аміногуанідин & $\begin{array}{c}3,79 \pm 0,13 \\
p_{1}<0,001\end{array}$ & $\begin{array}{c}21,82 \pm 0,85 \\
p_{1}<0,005\end{array}$ & $\begin{array}{c}2,94 \pm 0,08 \\
p_{1}<0,01\end{array}$ & $\begin{array}{c}15,28 \pm 0,78 \\
\mathrm{p}_{1}<0,05\end{array}$ \\
\hline
\end{tabular}


На сьогодні відсутні переконливі докази есрективності застосування модуляторів синтезу NO для попередження передчасних пологів та життєздатності плодів при АФС. Отже, пошук серед модуляторів синтезу NO ефективних засобів корекції порушень, що виникають при АФС, $€$ актуальним завданням. Важливість його підтверджується відсутністю єдиної точки зору щодо ролі системи NO в розвитку АФС.

Це спонукає до пошуку нових можливих шляхів поєднання дії L-аргініну та інших біологічно активних сполук, що сприятиме ефективнішій корекції ураження головного мозку у вагітних мишей лінії BALB/с за умов АФС. Метаболізм L-аргініну здійснюється шляхом окисного перетворення з участю NO-синтази до NO та L-цитруліну і неокисного з участю аргінази (3.5.3.1) до сечовини й орнітину [26]. Аміногуанідин - це нуклеофрільна гідразинова сполука, структурний аналог L-аргініну, який $є$ конкурентним інгібітором цитокініндукованої ізоформи NOS - iNOS $[27,28]$.

Як показали результати наших досліджень, на тлі комбінованого застосування попередника синтезу NO L-аргініну та селективного інгібітора iNOS аміногуанідину вміст у мозочку мишей лінії BALB/c з АФС NO${ }_{2}^{-}$знижувався на $28 \%$, а NO ${ }_{3}^{-}-$ на $17 \%$ порівняно з показниками тварин з АФС. При введенні тваринам з AФC L-аргініну в комбінації з аміногуанідином вміст у великих півкулях головного мозку $\mathrm{NO}_{2}{ }^{-}$зменшувався на $16 \%$, а $\mathrm{NO}_{3}^{-}$- на $10 \%$ відносно групи мишей з АФС (див. табл. 1).

На тлі комбінованого використання L-аргініну та аміногуанідину вміст $\mathrm{NO}_{2}^{-}$- мозочку мишей лінії BALB/с з АФС на 18-й день вагітності знижувався на $29 \%$, а $\mathrm{NO}_{3}^{-}$- на $25 \%$ порівняно 3 показниками групи вагітних тварин з АФС (див. табл. 2). При введенні L-аргініну в комбінації 3 аміногуанідином вміст $\mathrm{NO}_{2}-$ у великих півкулях головного мозку тварин з АФС на 18-й день вагітності зростав на $21 \%$, а $\mathrm{NO}_{3}^{-}$- на $22 \%$ відносно 5-ї групи вагітних мишей лінії BALB/c 3 АФС.

Таким чином, комбіноване застосування попередника синтезу NO L-аргініну та селективного інгібітора iNOS аміногуанідину призводило до нормалізації рівня стабільних метаболітів синтезу оксиду азоту $-\mathrm{NO}_{2}^{-}$і $\mathrm{NO}_{3}^{-}$у мозочку та великих півкулях головного мозку мишей лінії BALB/c за умов AФС до і на 18-й день вагітності.

ВИСНОВКИ. 1. У мишей лінії BALB/с з антифроссроліпідним синдромом у мозочку та великих півкулях головного мозку зростав вміст стабільних метаболітів оксиду азоту - нітрит- і нітрат-аніонів порівняно з показниками інтактних тварин.

2. При експериментальному антифоссроліпідному синдромі на 18-й день вагітності вміст нітрит- і нітрат-аніонів у мозочку збільшувався, а у великих півкулях головного мозку тварин 3 антифоосфоліпідним синдромом зменшувався відносно контролю.

3. На тлі комбінованого введення мишам 3 антисроссроліпідним синдромом попередника синтезу оксиду азоту L-аргініну та селективного інгібітора індуцибельної NO-синтази аміногуанідину відзначали зниження вмісту нітрит-і нітратаніонів у мозочку та великих півкулях головного мозку порівняно з показниками тварин із цим синдромом.

4. У вагітних мишей лінії BALB/с з антифосфоліпідним синдромом, яким вводили L-аргінін у комбінації з аміногуанідином, відмічали зменшення вмісту нітрит- і нітрат-аніонів у мозочку та його збільшення у великих півкулях головного мозку відносно групи тварин із цим синдромом на 18-й день вагітності.

\section{СПИСОК ЛІТЕРАТУРИ}

1. Васильев Д. В. Антифоосфолипидный синдром: клиника и генетика тромботических проявлений I Д.В.Васильев, Л. В. Чернобай, О.В.Васильева // Укр. журн. медицини, біології та спорту. - 2019. № 2 (4). - C. 161-167.

2. Показники прооксидантно-антиоксидантної системи печінки при експериментальному антифосфоліпідному синдромі та застосуванні L-аргініну / О. З. Яремчук, К. А. Посохова, А. Р. Брик [та ін.] // Мед. та клініч. хімія. - 2017. - 19, № 3 (72). - С. 63-70.
3. Ульянова О. В. Особенности неврологических проявлений у пациентов с антифосфролипидным синдромом / О. В. Ульянова, В. А. Куташов, Т. Ю. Хабарова // Вестн. КазНМУ. - 2016. - № 2. - С. 333-338.

4. Яремчук О. 3. Вплив L-аргініну та аміногуанідину на показники вільнорадикального окиснення у нирках при експериментальному антисросфоліпідному синдромі / О. 3. Яремчук, К. А. Посохова, М. І. Куліцька // Світ медицини та біології. - 2018. - № 3 (65). C. 210-214. 
5. Калашникова Л. А. Антифросфолипидный синдром с неврологическими проявлениями, имитирующими рассеянный склероз / Л. А. Калашникова, Б. Д. Джамантаева // Нейрохирургия и неврология Казахстана. - 2015. - № 1 (38). - С. 15-23.

6. Neurological manifestations in patients with antiphospholipid syndrome / M. Etemadifar, L. Dehghani, S. Tahani [et al.] // Iran J. Neurol. - 2013. - No. 12 (4). P. 172-175.

7. Ahluwalia J. The Laboratory diagnosis of the antiphospholipid syndrome / J. Ahluwalia, S. Sreedharanunni // Indian J. Hematol. Blood Transfus. - 2017. - 33 No. 1. - P. 8-14. doi: 10.1007/s12288-016-0739-y

8. Antiphospholipid antibodies overlapping in isolated neurological syndrome and multiple sclerosis: neurobiological insights and diagnostic challenges / C. D’Angelo, O. Franch, L. Fernández-Paredes [et al.] // Front. Cell. Neurosci. - 2019. - 13. - P. 107. doi: 10.3389/ fncel.2019.00107

9. The role of beta-2-glycoprotein I in health and disease associating structure with function: more than just APS / T. McDonnell, C. Wincup, I. Buchholz [et al.] // Blood Reviews. -2019. - No. 33.-P. 100610 doi:10.1016/j. blre.2019.100610

10. Посохова К. А. Акушерський антифоосфоліпідний синдром і система оксиду азоту (огляд літератури і результати власних досліджень) / К. А. Посохова, І. Ю. Сак, С. Р. Сампара // Мед. хімія. - 2014. - 16, № 1 (58). - C. 73-80.

11. Clinical relevance of nitric oxide metabolites and nitrative stress in thrombotic primary antiphospholipid syndrome / P. R. Ames, J. R. Batuca, A. Ciampa [et al.] // J Rheumatol. - 2010. - No. 37 (12). - P. 2523-2530. doi:10.3899/jrheum.100494C1.

12. Oxidative stress in the pathogenesis of atherothrombosis associated with antiphospholipid syndrome and systemic lupus erythematosus: new therapeutic approaches / C. Lopez-Pedrera, N. Barbarroja, Y. Jimenez-Gomez [etal.]//Rheumatology. -2016. - № 55 (12). P. 2096-2108. doi: 10.1093/rheumatology/kew054

13. Antiphospholipid antibodies are associated with enhanced oxidative stress, decreased plasma nitric oxide and paraoxonase activity in an experimental mouse model // J. D. Alves, L. J. Mason, P. R. J. Ames [et al.] // Rheumatology. - 2005. - No. 44 (10). - P. 1238-1244. doi: 10.1093/rheumatology/keh722

14. Mechanisms of Endothelial Dysfunction in Antiphospholipid Syndrome: Association With Clinical Manifestations / M. Velasquez, M. Rojas, V. M. Abrahams [et al.] // Front. Physiol. - 2018. - Vol. 21, No. 9 - P. 1840. doi: 10.3389/fphys.2018.01840 (2018)

15. Насонов Е. Л. Антифооссролипидный синдром / Е. Л. Насонов. - М. : Литтерра, 2004. - 440 с.

16. Гемодинамика мозга: глутаматергическая система и цикл оксида азота в регуляции мозгового кровообращения. Новая концепция / В.П.Реутов,

\section{REFERENCES}

1.Vasilyev, D.V., Chernobay, L.V., \& Vasilyeva, O.V. (2019). Antifosfolipidnyy sindrom: klinika i genetika trom-
Е. Г. Сорокина, Н. В. Самосудова [и др.] // Рacific Medical Journal. - 2017. - № 3. - C. 37-45.

17. Куровська В. О. Роль оксиду азоту в ішемічних і ішемічнореперфузійних ушкодженнях головного мозку / В. О. Куровська, В. П. Пішак, С. С. Ткачук // Буковин. мед. вісн. - 2008. - 12, № 4. - С. 143-149.

18. Морфологічний стан матки та плаценти при експериментальному моделюванні гестаційного антисросфроліпідного синдрому на мишах / Г.В.Зайченко, Ю. Б. Лар'яновська, Т. В. Деєва [та ін.] // Укр. мед. альм. - 2011. - 14, № 4. - С. 136-141.

19. Камышников В. С. Справочник по клинико-биохимическим исследованиям и лабораторной диагностике / В. С. Камышников. - М. : МЕДпресс-информ, 2004. - 920 c

20. Analisis of nitrate, nitrite and $\left[{ }^{15} \mathrm{~N}\right]$ nitrate in biological fluids / L. C. Green, A. W. Davie, J. Golawski [et al.] // Anal. Biochem. - 1982. - 126 (1). - P. 131-138. doi: 10.1016/0003-2697(82)90118-X

21. Кіселик I. О. Особливості визначення нітратів та нітритів у крові хворих на вірусні гепатити та жовтяниці іншої етіології / . О. Кіселик, М. Д. Луцик, Л. Ю. Шевченко // Лаб. діагностика. - 2001. - № 3. - С. 43-45.

22. Antiphospholipid antibodies promote leukocyteendothelial cell adhesion and thrombosis in mice by antagonizing eNOS via beta2GPI and apoER2 / S. Ramesh, C. N. Morrell, C. Tarango [et al.] // J. Clin. Invest. 2011. - No. 121 (1). - P. 120-131. doi: 10.1172/JCI39828.

23. Максимович Н. Е. Понятие о нитроксидергической системе мозга (роль нейрональных источников) / Н. Е. Максимович // Журн. ГГМУ. - 2003. - № 4. C. 7-10.

24. Киселева А. В. Роль оксида азота в повреждении нейронов при критических состояниях / А. В. Киселева, Ю. А. Чурляев, Е. В. Григорьев // Общая реаниматология. - 2009. - 5, № 5. - С. 80-84.

25. Increased levels of proinflammatory cytokines and nitric oxide metabolites in neuropsychiatric lupus erythematosus / E. Svenungsson, M. Andersson, L. Brundin [et al.] // Ann. Rheum. Dis. - 2001. - No. 60. P. 372-379.

26. Северьянова Л. А. Механизмы действия аминокислоты L-аргинина на нервную и иммунную регуляторные системы / Л. А. Северьянова, И. И. Бобынцев // Курский науч.-практ. вестн. "Человек и его здоровье". - 2006. - № 3. - С. 60-75.

27. Effects of aminoguanidine on nitric oxide production induced by inflammatory cytokines and endotoxin in cultured rat hepatocytes / G. L. Zhang, Y. H. Wang, H. L. Teng [et al.] // World J. Gastroenterol. - 2001. - 7, No. 3. - P. 331-334. doi: 10.3748/wjg.v7.i3.331

28. Increased inducible nitric oxide synthase and arginase II expression in heart failure: no net nitrite/nitrate production and protein S-nitrosylation / P. Heush, S. Aker, K. Boenger [et al.] // Am. J. Physiol. Heart Circ. Physiol. 2010. - No. 299 (2). - P. 446-453. doi: 10.1152/ajpheart. 01034.2009

boticheskikh proiavleniy [Antiphospholipid syndrome: clinic and genetics of thrombotic manifestations]. Ukrain- 
skyi zhurnal medytsyny, biolohii ta sportu - Ukrainian Journal of Medicine, Biology and Sport, 2 (4), 161-167 [in Russian].

2. Yaremchuk, O.Z., Posokhova, K.A., Bryk, A.R., Kulitska, M.I., Kuzmak, I.P., \& Mehno, N.Ya. (2017). Pokaznyky prooksydantno-antyoksydantnoi systemy pechinky pry eksperymentalnomu antyfosfolipidnomu syndromi ta zastosuvanni L-arhininu [Parameters of liver prooxidative-antioxidant system in cases of experimental antiphospholipid syndrome and L-arginin administration]. Medychna ta klinichna khimiia - Medical and Clinical Chemistry, 19 (3), 63-70 [in Ukrainian].

3. Ulyanova, O.V., Kutashov, V. A., \& Khabarova, T.Yu. (2016). Osobennosti nevrologicheskikh proyavleniy u patsientov s antifosfolipidnym sindromom [Features of neurological manifestations in patients with antiphospholipid syndrome]. Vestnik KazNMU - Bulletin of KazNMU, 2, 333-338 [in Russian].

4. Yaremchuk, O.Z., Posokhova, K.A., \& Kulitska, M.I. (2018). Vplyv L-arhininu ta aminohuanidynu na pokaznyky vilnoradykalnoho okysnennia u nyrkakh pry eksperymentalnomu antyfosfolipidnomu syndromi [Influence of $\mathrm{L}$-arginin and aminoguanidine on renal free-radical oxidation rates in cases of experimental antiphospolipid syndrome]. Svit medytsyny ta biolohii - World of Medicine and Biology, 3 (65), 210-214 [in Ukrainian].

5. Kalashnikova, L.A., \& Dzhamantaeva, B.D. (2015). Antifosfolipidnyy sindrom s nevrologicheskimi proyavleniyami, imitiruyushchimi rasseyannyy skleroz [Antiphospholipid syndrome with neurological manifestations that mimic multiple sclerosis]. Neirokhirurgiya i nevrologiya Kazakhstana - Neurosurgery and Neurology of Kazakhstan, 1 (38), 15-23 [in Russian].

6. Etemadifar, M., Dehghani, L., Tahani, S., Toghianifar, N., Rahaimi, M., \& Eskandari, N. (2013). Neurological manifestations in patients with antiphospholipid syndrome. Iran J. Neurol., 12 (4), 172-175.

7. Ahluwalia, J., \& Sreedharanunni, S. (2017). The Laboratory diagnosis of the antiphospholipid syndrome. Indian J. Hematol. Blood Transfus., 33 (1), 8-14. doi: 10.1007/s12288-016-0739-y

8. D’Angelo, C., Franch, O., Fernández-Paredes, L., Oreja-Guevara, C., Núñez-Beltrán, M., Comins-Boo, A., ... Sanchez-Ramon S. (2019). Antiphospholipid antibodies overlapping in isolated neurological syndrome and multiple sclerosis: neurobiological insights and diagnostic challenges. Front. Cell. Neurosci., 13, 107. doi: 10.3389/fncel.2019.00107

9. McDonnell, T., Wincup, C., Buchholz, I., Pericleous, C., Giles, I., Ripoll, V., ...Rahman, A. (2019). The role of beta-2-glycoprotein I in health and disease associating structure with function: more than just APS. Blood Reviews., 33, 100610 doi:10.1016/j.blre.2019. 100610

10. Posokhova, K.A., Sak, I.Yu., \& Sampara, S.R. (2014). Akusherskyi antyfosfolipidnyi syndrom i systema oksydu azotu (ohliad literatury i rezultaty vlasnykh doslidzhen) [Obstetric antiphospholipid syndrome and system of nitric oxide (review and results of own research)]. Medychna khimiia - Medical Chemistry, 16 (1), 73-80 [in Ukrainian].

11. Ames, P.R.J., Batuca, J.R., Ciampa, A., Ccone, L.I., \& Alves, J.D. (2010). Clinical relevance of nitric oxide metabolites and nitrative stress in thrombotic primary antiphospholipid syndrome. The Journal of
Rheumatology, 37 (12), 2523-2530. doi:10.3899/ jrheum.100494C1.

12. Lopez-Pedrera, Ch., Barbarroja, N., JimenezGomez, Y., Collantes-Estevez, E., Aguirre, M.A., \& Cuadrado, M.J. (2016). Oxidative stress in the pathogenesis of atherothrombosis associated with antiphospholipid syndrome and systemic lupus erythematosus: new therapeutic approaches. Rheumatology, 55, 2096-2108. doi: 10.1093/rheumatology/kew054

13. Alves, J.D., Mason, L.J., \& Ames P.R.J. (2005). Antiphospholipid antibodies are associated with enhanced oxidative stress, decreased plasma nitric oxide and paraoxonase activity in an experimental mouse model. Rheumatology, 44, 1238-1244. doi: 10.1093/rheumatology/keh722

14. Velasquez, M., Rojas, M., Abrahams, V.M., Escudero, C., \& Cadavid, A.P. (2018). Mechanisms of Endothelial Dysfunction in Antiphospholipid Syndrome: Association with Clinical Manifestations. Front. Physiol., 21 (9), 1840. doi: 10.3389/fphys.2018.01840 (2018)

15. Nasonov, E.L. (2014). Antifosfolipidnyy sindrom [Antiphospholipid syndrome]. Moscow: Litterra [in Russian].

16. Reutov, V. P., Sorokina, E.G., \& Samosudova, N.V. (2017). Gemodinamika mozga: glutamatergicheskaya sistema i tsikl oksida azota $v$ regulyatsii mozgovogo krovoobrashcheniya. Novaya kontseptsiya [Brain hemodynamics: glutamatergic system and nitric oxide cycle in the regulation of cerebral circulation. New concept]. Tikhookeanskiy meditsinskiy zhurnal - Pacific Medical Journal, 3, 37-45 [in Russian].

17. Kurovska, V.O., Pishak, V.P., \& Tkachuk, S.S. (2008). Rol oksydu azotu $v$ ishemichnykh i ishemichnoreperfuziinykh ushkodzhenniakh holovnoho mozku [The role of nitric oxide in ischemic and ischemic reperfusion brain damage]. Bukovynskyi medychnyi visnyk Bukovyna Medical Bulletin, 12 (4), 143-149 [in Ukrainian].

18. Zaichenko, H.V., Larianovska, lu.B., \& Deieva, T.V. (2011). Morfolohichnyi stan matky ta platsenty pry eksperymentalnomu modeliuvanni hestatsiinoho antyfosfolipidnoho syndromu na myshakh [Morphological state of the uterus and placenta in experimental modeling of gestational antiphospholipid syndrome in mice]. Ukrainskyi medychnyi almanakh - Ukrainian Medical Almanac, 14 (4), 136-141 [in Ukrainian].

19. Kamyshnikov, V.S. (2004). Spravochnik po kliniko-biokhimicheskim issledovaniyam i laboratornoy diagnostike [Manual on clinical biochemical research and laboratory diagnostics]. Moscow: MEDpress-inform [in Russian].

20. Green, L.C., David, A.W., Golawski, J., Skipper, P.L., Wishnok, J.S., \& Tannenbaum, S.R. (1982). Analisis of nitrate, nitrite and $\left[{ }^{15} \mathrm{~N}\right]$ nitrate in biological fluids. Anal. Biochem., 126 (1), 131-138. doi: 10.1016/ 0003-2697(82)90118-x

21. Kiselyk, I.O., Lutsyk, M.D., \& Shevchenko, L.Yu. (2001). Osoblyvosti vyznachennia nitrativ ta nitrytiv u krovi khvorykh na virusni hepatyty ta zhovtianytsi inshoi etiolohii [Features of determination of nitrates and nitrites in blood of patients with viral hepatitis and jaundice of other etiology]. Lab. diahnostyka - Lab. Diagnostics, 3, 43-45 [in Ukrainian].

22. Ramesh, S., Morrell, C. N., Tarango, C., Thomas, G.D., Yuhanna, I.S., Girardi G., ... Mineo, Ch. (2011). Antiphospholipid antibodies promote leukocyte- 
endothelial cell adhesion and thrombosis in mice by antagonizing eNOS via beta2GPI and apoER2. J. Clin. Invest., 121 (1), 120-131. doi: 10.1172/JCl39828.

23. Maksimovich, N.E. (2003). Poniatie o nitroksidergicheskoy sisteme mozga (rol neyronalnykh istochnikov) [The concept of the nitroxidergic system of the brain (the role of neuronal sources)]. Zhurnal GGMU Magazine GSMU, 4, 7-10 [in Russian].

24. Kiseleva, A.V., Churlyaev, Yu.A., \& Grigoryev, E.V. (2019). Rol oksida azota $v$ povrezhdenii neyronov pri kriticheskikh sostoyaniyakh [The role of nitric oxide in damage to neurons in critical conditions]. Obshchaya reanimatologiya - General Resuscitation, 5, 80-84 [in Russian]. doi: 10.15360/1813-9779-2009-5-80

25. Svenungsson, E., Andersson, M., Brundin, L., van Vollenhoven, R., Khademi, M., Tarkowski, A., ... Olsson, T. (2001). Increased levels of proinflammatory cytokines and nitric oxide metabolites in neuropsychiatric lupus erythematosus. Ann. Rheum. Dis., 60, 372-379. doi: 10.1136/ard.60.4.372
26. Severyanova, L.A., \& Bobyntsev, I.I. (2006). Mekhanizmy deystviya aminokisloty L-arginina na nervnuyu i immunnuyu reguliatornye sistemy [The mechanisms of action of the amino acid L-arginine on the nervous and immune regulatory systems]. Kurskiy nauchno-prakticheskiy vestnik "Chelovek i ego zdorove" - Kursk Scientific and Practical Bulletin "People and his Health", 3, 60-75 [in Russian].

27. Zhang, G.L., Wang, Y.H., Teng H.L., \& Lin, Z.B. (2001). Effects of aminoguanidine on nitric oxide production induced by inflammatory cytokines and endotoxin in cultured rat hepatocytes. World J. Gastroenterol., 7 (3), 331-334. doi: 10.3748 / wjg.v7.i3.331

28. Heush, P., Aker, S., Boenger, K., Deindl, E., van de Sand, A., Klein, K., ...Schulz, R. (2010). Increased inducible nitric oxide synthase and arginase II expression in heart failure: no net nitrite/nitrate production and protein S-nitrosylation. Am. J. Physiol. Heart Circ. Physiol., 299 (2), 446-453. doi: 10.1152/ajpheart.01034.2009

О. 3. Яремчук, Е. А. Посохова, И. П. Кузьмак ТЕРНОПОЛЬСКИЙ НАЦИОНАЛЬНЫЙ МЕДИЦИНСКИЙ УНИВЕРСИТЕТ ИМЕНИ И. Я. ГОРБАЧЕВСКОГО МОЗ УКРАИНЫ

\section{ВЛИЯНИЕ L-АРГИНИНА И АМИНОГУАНИДИНА НА УРОВЕНЬ СИНТЕЗА ОКСИДА АЗОТА В МОЗЖЕЧКЕ И БОЛЬШИХ ПОЛУШАРИЯХ ГОЛОВНОГО МОЗГА В УСЛОВИЯХ ЭКСПЕРИМЕНТАЛЬНОГО АНТИФОСФОЛИПИДНОГО СИНДРОМА}

\section{Резюме}

Вступление. Антияросфролипидный синдром (АФС) - это аутоиммунное заболевание, характеризующееся наличием антифоссолипидных антител, артериальными и венозными тромбозами, тромбоцитопенией, невынашиванием беременности.

Цель исследования - изучить влияние комбинированного действия L-аргинина и аминогуанидина на содержание нитрит - и нитрат-анионов в мозжечке и больших полушариях головного мозга мышей линии $B A L B / c$ c антифоссролипидным синдромом до и на 18-й день беременности.

Методы исследования. Исследования выполняли на мышах-самках линии BALB/c из смоделированным АФС. Для коррекции использовали L-аргинин (25 мг/кг) в комбинации с аминогуанидином (10 мг/кг). O содержании оксида азота в гомогенатах мозжечка и больших полушариях головного мозга животных с АФС до и на 18-й день беременности делали вывод по количеству его стабильных метаболитов - нитрит-анионов $\left(\mathrm{NO}_{2}^{-}\right)$и нитрат-анионов $\left(\mathrm{NO}_{3}^{-}\right)$.

Результаты и обсуждение. У мышей линии BALB/C с АФС в мозжечке и больших полушариях головного мозга возрастало содержание стабильных метаболитов оксида азота - $\mathrm{NO}_{2}^{-}$и $\mathrm{NO}_{3}^{-}$по сравнению с показателями интактных животных. При экспериментальном АФС на 18-й день беременности содержание $\mathrm{NO}_{2}^{-}$и $\mathrm{NO}_{3}^{-}$в мозжечке увеличивалось, а в больших полушариях головного мозга животных с АФС уменьшалось относительно контроля. На фроне комбинированного введения мышам с АФС предшественника синтеза оксида азота L-аргинина и селективного ингибитора индуцибельной NO-синтазы аминогуанидина отмечали снижение содержания $\mathrm{NO}_{2}^{-}$и $\mathrm{NO}_{3}^{-}$в мозжечке (на 28 и 17 \%) и больших полушариях головного мозга (на 16 и 10 \%) по сравнению с показателями животных с АФС. У беременных мышей линии BALB/c с АФC, которым вводили L-аргинин в комбинации с аминогуанидином, наблюдали уменьшение содержания $\mathrm{NO}_{2}^{-}$на $29 \%$ и $\mathrm{NO}_{3}^{-}$на $25 \%$ в мозжечке, увеличение уровня $\mathrm{NO}_{2}^{-}$на $21 \%$ и NO${ }_{3}^{-}$на $22 \%$ в больших полушариях головного мозга относительно беременных самок с АФС.

Вывод. Комбинированное применение $L$-аргинина и аминогуанидина приводит к нормализации уровня стабильных метаболитов синтеза оксида азота - $\mathrm{NO}_{2}^{-}$и $\mathrm{NO}_{3}^{-}$в мозжечке и больших полушариях головного мозга мышей линии BALB/с в условиях АФС до и на 18-й день беременности.

КЛЮЧЕВЫЕ СЛОВА: антифоссролипидный синдром; беременность; оксид азота; мозжечок; большие полушария головного мозга. 


\section{INFLUENCE OF L-ARGININE AND AMINOGUANIDINE ON THE LEVEL OF SYNTHESIS OF NITRIC OXIDE IN THE CEREBELLUM AND CEREBRAL HEMISPHERES IN EXPERIMENTAL ANTIPHOSPHOLIPID SYNDROME}

\section{Summary}

Introduction. Antiphospholipid syndrome (APS) is an autoimmune disease characterized by the presence of antiphospholipid antibodies, arterial and venous thrombosis, thrombocytopenia, miscarriage.

The aim of the study - to investigate the effect of the combined effect of $L$-arginine and aminoguanidine on the content of nitrite anions $\left(\mathrm{NO}_{2}^{-}\right)$and nitrate anions $\left(\mathrm{NO}_{3}^{-}\right)$in the cerebellum and cerebral hemispheres of BALB/C mice with APS before pregnancy and on the $18^{\text {th }}$ day of pregnancy.

Research Methods. The study was performed on female BALB/c mice, for which APS was simulated. L-arginine $(25 \mathrm{mg} / \mathrm{kg})$ in combination with aminoguanidine $(10 \mathrm{mg} / \mathrm{kg})$ was used for correction. The content of NO in the homogenates of cerebellum and cerebral hemispheres of the animals with APS before pregnancy and on the $18^{\text {th }}$ day of pregnancy was determined by the number of its stable metabolites of nitrite anions $\left(\mathrm{NO}_{2}^{-}\right)$and nitrate anions $\left(\mathrm{NO}_{3}^{-}\right)$.

Results and Discussion. The content of stable metabolites of nitric oxide $\mathrm{NO}_{2}^{-}$and $\mathrm{NO}_{3}^{-}$in the cerebellum and cerebral hemispheres increased in the BALB/c mice with APS compare to the intact animals. In cases of experimental APS, on the $18^{\text {th }}$ day of pregnancy, an increase in the content of $\mathrm{NO}_{2}^{-}$and $\mathrm{NO}_{3}^{-}$in the cerebellum was evidenced, as well as a decrease in $\mathrm{NO}_{2}^{-}$and $\mathrm{NO}_{3}^{-}$in the brain hemispheres of the animals with APS compare to the controls. In case of the combined administration of precursor of synthesis of NO L-arginine and a selective inhibitor of iNOS aminoguanidine into the animals with APS, a decrease in the content of $\mathrm{NO}_{2}^{-}$and $\mathrm{NO}_{3}^{-}$in the cerebellum (by $28 \%$ and $17 \%$ ) and cerebral hemispheres (by $16 \%$ and $10 \%$ ) was evidenced comparing to the animals with APS. In the pregnant BALB/c mice with APS administered with L-arginine in combination with aminoguanidine, a decrease of $\mathrm{NO}_{2}^{-}$by $29 \%$ and $\mathrm{NO}_{3}^{-}$by $25 \%$ in cerebellum, an increase of $\mathrm{NO}_{2}^{-}$by $21 \%$ and $\mathrm{NO}_{3}^{-}$by $22 \%$ in the cerebral hemispheres was evidenced comparing to those of the pregnant females with APS.

Conclusions. It has been established that the combined use of the precursor of synthesis of NO L-arginine and a selective inhibitor iNOS aminoguanidine leads to normalization of the level of stable metabolites of $\mathrm{NO}_{2}^{-}$and $\mathrm{NO}_{3}^{-}$nitric oxide synthesis in the cerebellum and cerebral hemispheres of the BALB/c mice with APS before pregnancy and on the $18^{\text {th }}$ day of pregnancy.

KEY WORDS: antiphospholipid syndrome; pregnancy; nitric oxide; cerebellum; cerebral hemispheres.

Отримано 22.10.19

Адреса для листування: О. З. Яремчук, Тернопільський національний медичний університет імені І. Я. Горбачевського мОз України, майдан Волі, 1, Тернопіль, 46001, Україна, e-mail: yaremchuk@tdmu.edu.ua. 